\title{
APPLICATION OF GIS IN SELECTION OF LOCATION FOR CONSTRUCTION OF NUCLEAR POWER PLANTS IN SERBIA
}

\author{
Nikola Ćorović1*, Uroš Durlević* \\ *University of Belgrade, Faculty of Geography, Studentski trg 3/III, 11000 Belgrade, \\ Serbia
}

\begin{abstract}
The use of nuclear energy in the world represents one of the main alternatives to fossil fuels. Significant greenhouse gas emissions from fossil fuel combustion could be replaced by cleaner energy such as nuclear. In this paper, by using Geographic Information Systems (GIS), available databases and Analytic hierarchy process (AHP), the results in the selection of the location for the construction of nuclear power plants (NPP) in Serbia were obtained. The research area includes zones between large rivers (Danube, Sava, Tisa, Velika Morava) with an area of $8757.45 \mathrm{~km}^{2}$. An analysis of natural (seismicity, geological background, hypsometry, slope of the terrain, distance from faults, ground cover, land use method) and anthropogenic conditions (distance from the state border, settlements, roads and railways) was carried out, with the elimination of protected areas from further research due to of its ecological significance. After multi-criteria analysis, weighting coefficients were assigned for each criterion using the AHP method. The results showed that $0.02 \%$ of the area is suitable, and $8.68 \%$ partially suitable for the construction of nuclear power plants. This paper provides an adequate overview of the most suitable locations for the use of nuclear energy, so that the obtained results can be applied in further research by national services in charge of nuclear sciences.
\end{abstract}

Key words: nuclear power plants, GIS, Serbia, AHP

${ }^{1}$ Corresponding author: N. Ćorović, University of Belgrade, Faculty of Geography, Studentski trg 3/III, 11000 Belgrade, Serbia; e-mail: corovic.nikola.nc@gmail.com 


\section{Introduction}

Not so long ago, solutions to many problems of human society were expected from mastering of nuclear energy. The first nuclear power plant was put into operation in the 1950s. Today, nuclear energy provides about $10 \%$ of the world's electricity from about 450 nuclear reactors (World Nuclear Association, 2021). Nuclear technology uses energy released by the splitting of atoms of certain elements.

Global energy demand is projected to grow significantly over the next 50 years. Much of that demand will come from parts of the world where energy consumption is relatively low compared to developed countries and which will be increasingly included in the global economy (Kristiansen, 2017; Cvetković et al., 2021). As demand grows, the world community will face a serious challenge - producing enough energy to meet economic growth and improve social development while, on the other hand, the environment needs to be protected and improved. There is no doubt that it is a great responsibility of decision-makers to establish appropriate policies that would adequately address this challenge. Among the various energy sources that contribute to the world's reserves, nuclear energy ranks first in terms of complexity in decision-making. The economic, technological and social consequences of nuclear energy make every decision far more demanding and difficult. Serious questions that our society raises about nuclear energy include the safety of installations, the disposal of radioactive waste, the ability of nuclear energy to reduce greenhouse gas emissions, and a handful of questions about nuclear weapons (Nuclear Energy Agency, 2003). From the environmental aspect, the impact of nuclear energy exploitation on population and biodiversity is studied, but also on air, soil and water quality (Langović et al., 2017; Doderović et al., 2020; Durlević, 2020).

Electricity obtained in reactors through a controlled process of nuclear fission has great advantages over fossil fuels, from significantly lower fuel consumption ( $1 \mathrm{~g}$ of uranium replaces 2.5 tons of high quality coal), minimal $\mathrm{CO}_{2}$ emissions into the atmosphere, lower prices of $1 \mathrm{kWh}$ of produced electricity (Хајдин \& Поломчић, 2016).

The biggest shortcomings refer to nuclear safety, which is associated with catastrophic and long-lasting consequences in case of accidents, then the problems of storing of used-up nuclear fuel that remains radioactive for thousands of years, then declining uranium reserves in the world, 
Application of GIS in selection

of location for construction of nuclear power plants in Serbia

and very expensive and long construction of nuclear power plants (NPP). Endangering the environment with the use of fossil fuels in recent years has strengthened the position of supporters of the use of nuclear energy, but it was enough that one accident, such as the last one in the Fukushima Daiichi NPP in Japan, to question all its benefits, and in many countries even to ban the use of this type of energy (Preston et al., 2007; Visschers \& Siegrist, 2013; Neumann \& Hopf, 2013; Park \& Ohm, 2014; Rhodes, 2014; Ercan et al., 2015; Fukunaga, 2021). Since the Chernobyl disaster in 1986 (Borzilov \& Klepikova, 1993; Makhonko et al., 1996; Bennett et al., 2006; Saenko et al., 2011) in European countries, a moratorium on the construction of NPP is still in force (Хајдин \& Поломчић, 2016). Public concern is growing when it comes to the application of nuclear energy, especially after major nuclear disasters (Peters \& Slovic, 1996; Sjöberg, 2000; Viklund, 2004; Smith, 2013; Sundström \& McCright, 2016; Filipović \& Kešetović, 2017). With the approval of the Law on the Prohibition of the Construction of Nuclear Power Plants in the Federal Republic of Yugoslavia, a moratorium was introduced in Serbia, which prohibits not only the construction of nuclear power plants but also their development. The ban also applies to investment decisions, implementation of investment plans and technical documentation for the construction of nuclear power plants, nuclear fuel production plants and used-up nuclear fuel reprocessing plants. Due to this ban, the study of nuclear energy and technology in higher education institutions has been reduced to a minimum (Cvetković et al., 2021).

Serbia, which has no NPP, is surrounded by nuclear reactors, most of which are on the Danube, a transit river. In the vicinity of Serbia, in the diameter of 600 kilometers, there are nuclear power plants "Krsko" in Slovenia, "Kozloduy" in Bulgaria, "Paks" in Hungary and "Cherna Voda" in Romania (Стојсављевић, 2008).

Using Geographic Information Systems (GIS), the paper will present potential locations for the construction of nuclear power plants in the territory of the Republic of Serbia through various criteria and analyzes. The research area covers a zone of 5 kilometers on both sides of the riverbed: Danube, Sava, Tisa and Velika Morava. This is one of the first papers in Serbia in which a modern methodology has been developed for the identification of the most suitable surfaces for the application of nuclear energy using software packages, databases and Analytic hierarchy process (AHP). 


\section{Materials and methods}

Study area

The study area covers a zone of five kilometers on both sides of the bed of four large rivers in the territory of the Republic of Serbia: the Danube, Sava, Tisa and Velika Morava. Due to their hydro potential, these river flows were taken into account for the needs of the analysis of the mentioned area. As the minimum flow for the smooth operation of a nuclear power plant is in the range from 130 to $150 \mathrm{~m}^{3} / \mathrm{s}$, the investigated watercourses meet this criterion and their coastline may represent potential locations for the construction of nuclear power plants. The research area covers an area of $8757.45 \mathrm{~km}^{2}$.

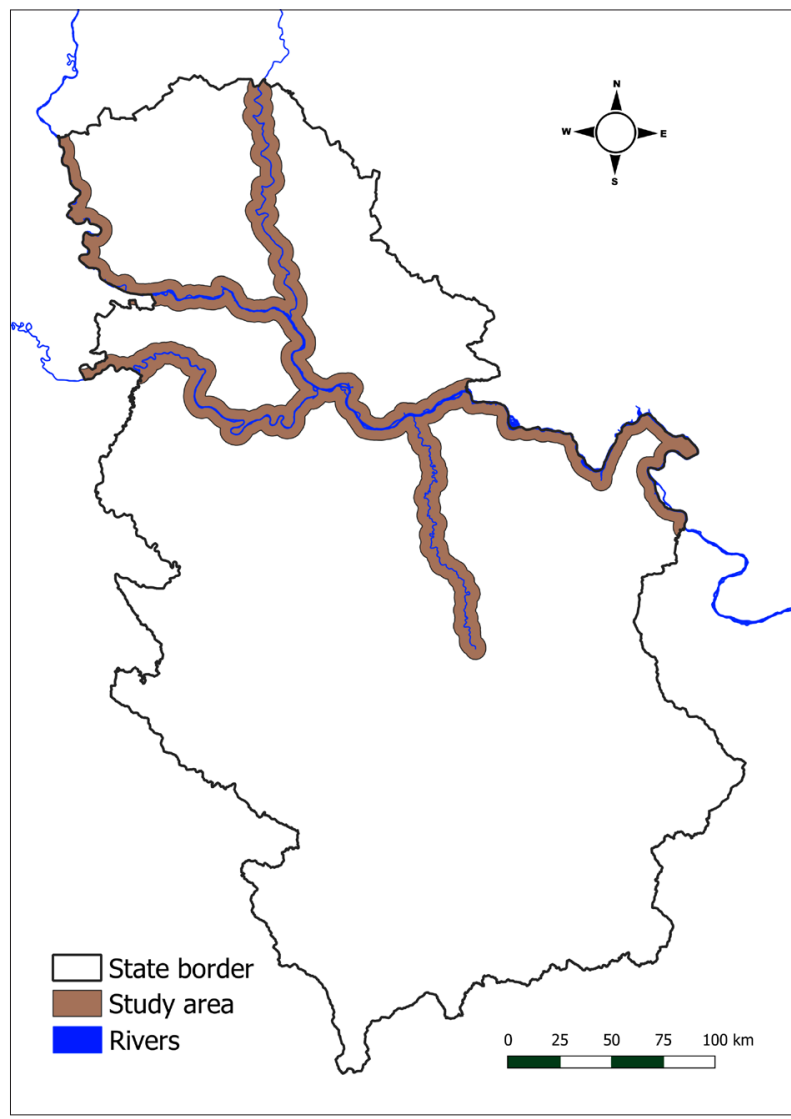

Figure 1. Geographical position 
Application of GIS in selection

of location for construction of nuclear power plants in Serbia

Depending on the type of cooling system to be applied in a nuclear power plant, large amounts of water are required. It is an essential part and is used daily, but is most necessary in the event of an accident when used to cool the core. In addition to the proximity of the river flow, important natural factors that were analyzed are: geological base, hypsometry, terrain slope, seismic hazard, faults and landslides, land use and pedological cover.

\section{Methodology}

Analytic hierarchy process (AHP) is a method of support in the decision-making process based on the formation of a hierarchy of problems and the original procedure for evaluating the elements by levels of the hierarchy until the final synthesis determines the weight of all elements at the lowest/highest level. Based on mathematics and human psychology, it was developed by Saaty (Saaty, 1980; Saaty 1990) and has been widely used worldwide ever since.

The AHP method is very flexible because it allows you to easily find connections between criteria and alternatives. This method approaches the relevance of real-world criteria and determines the interaction between the criteria, in the case of complex problems with many criteria and a relatively large number of alternatives. By applying this method, complex problems can be explained by a specific hierarchy, so that the analysis includes quantitative and qualitative aspects of the problem. AHP connects all levels of the hierarchy, which allows recognizing how a change in one criterion affects other criteria and alternatives (Forman \& Selly, 2001; AtanasovaPachemska et al. 2014). For the needs of analysis and interpretation of data and results, the software package QGIS 3.10 was used.

To obtain potential areas for the construction of nuclear power plants in the research area, the comparison of criteria in 3 groups was performed, and then the final comparison of the results obtained from each of the 3 groups separately. The criteria were placed in relation to each other, in order to then obtain matrices in order to further obtain the weighting coefficient for each criterion.

The first group that was analyzed were natural factors, the evaluation of seismic hazard was carried out, as well as geological base, hypsometry, slope of the terrain, ground cover and distance of the area from faults. 
Table 1. Evaluation of natural factors

\begin{tabular}{|c|c|c|c|}
\hline Seismic Hazard (MCS) & Grade & Hypsometry (m) & Grade \\
\hline VI-VII & 4 & $0-200$ & 5 \\
\hline VII & 3 & $200-400$ & 4 \\
\hline VII-VIII & 2 & $400-600$ & 3 \\
\hline \multirow[t]{2}{*}{ VIII } & 1 & $600-800$ & 2 \\
\hline & & $>800$ & 1 \\
\hline Rock type & Grade & Terrain slope $\left(^{\circ}\right)$ & Grade \\
\hline Alluvial sediments & 3 & $0-5$ & 5 \\
\hline River-swamp sediments & 3 & $5-10$ & 4 \\
\hline Facies of the bed & 2 & $10-15$ & 3 \\
\hline Facies of the flood period & 3 & $15-20$ & 2 \\
\hline Facies of the abandoned riverbed & 3 & $>20$ & 1 \\
\hline River terrace sediments & 3 & $\begin{array}{l}\text { Distance from } \\
\text { fault (km) }\end{array}$ & Grade \\
\hline River lake terrace & 3 & $0-5$ & 1 \\
\hline Deluvium-prolovium & 3 & $5-10$ & 2 \\
\hline Aeolian sediments & 4 & $10-15$ & 3 \\
\hline Tertiary clastic sediments & 1 & $15-20$ & 4 \\
\hline $\begin{array}{l}\text { Tertiary clastic and carbonate } \\
\text { sediments }\end{array}$ & 1 & $>20$ & 5 \\
\hline Flysch & 1 & Ground cover & Grade \\
\hline \multirow{2}{*}{$\begin{array}{c}\text { Mesozoic clastic sediments + } \\
\text { volcanoclastic rocks }\end{array}$} & \multirow{2}{*}{1} & Artificial surfaces & 1 \\
\hline & & Bare land & 5 \\
\hline $\begin{array}{l}\text { Mesozoic clastic and carbonate } \\
\text { sediments }\end{array}$ & 2 & Agricultural land & 3 \\
\hline $\begin{array}{l}\text { Mesozoic clastic and carbonate } \\
\text { sediments + volcanoclastic rocks }\end{array}$ & 2 & Grassy areas & 4 \\
\hline Mesozoic carbonate sediments & 3 & Shrubs & 4 \\
\hline Igneous rocks & 5 & Deciduous forests & 3 \\
\hline Diabase-corneal formation & 3 & Mixed forests & 3 \\
\hline Ultramafits & 3 & Evergreen forests & 3 \\
\hline Paleozoic clastic sediments & 2 & Wet soils & 2 \\
\hline Metamorphic rocks & 3 & Water surfaces & 1 \\
\hline
\end{tabular}

Seismic hazard is an extremely important factor in determining the locations for the application of nuclear energy and the aim is to keep the area where NPP would be planned, as seismically active as possible. A return period of 475 years was used for this research, and the data were taken from the Republic Seismological Institute. An indispensable factor in 
Application of GIS in selection

of location for construction of nuclear power plants in Serbia

the study of an area is the geological basis. When locating NPP one should be especially careful because on the composition of the rocks it depends whether a terrain is more or less prone to earthquakes, as well as landfalls and landslides. Tertiary clastic and carbonate sediments in which landslides are highly probable, but also flysch and Mesozoic clastic and carbonate sediments with volcanoclastic rocks do not represent adequate surfaces for NPP construction. On the other hand, magmatic rocks represent an ideal base for the construction of NPPs. Data on the geological base were obtained by analyzing the contents of the geological map of the SFRY.

Altitude is one of the important factors in locating nuclear power plants. Terrains up to 200 meters are suitable for construction, while with the increase in height, the possibility of proper construction decreases. The slope of the terrain represents a significant topographic parameter. The monitoring of hydrological phenomena, as well as the speed of surface water runoff, and the intensity of geomorphological processes, depend on the slope of the terrain. The most suitable terrains are those with a slope of $0^{\circ}$ to $5^{\circ}$ and occupy a significant part of the research area (more than $83 \%$ ). Data on altitude and slope of the terrain were obtained through a Digital Elevation Model (DEM) with a spatial resolution of 25 meters. We used the EU-DEM issued by the European Agency for Environmental Protection. Faults are the basic structural units in the lithosphere that are formed by moving parts of the rock mass along a crack called a paraclase or fault surface. According to the paraclase, parts of the rock mass can be raised, lowered and moved longitudinally under the influence of vertical and horizontal pressures (Шестановић, 1997). As such, they represent a very unfavorable part of the terrain and care should be taken that certain facilities, especially nuclear power plants, are not built in their immediate vicinity, but as far away from faults as possible.

The way of land use in the research area is extremely heterogeneous. There are as many as 27 classes, and the landscape is predominantly covered by agricultural areas with a share of $41.26 \%$, a significant area is occupied by deciduous forests with an area of $1405 \mathrm{~km}^{2}$ of the observed territory. The most favourable locations for the construction of nuclear power plants areas with sparse vegetation, have a spread of about $1.24 \mathrm{~km}^{2}$. A geospatial database (Corine Land Cover, 2018) issued by the European Environment Agency was used to obtain data on land use.

By digitizing the areas from the GeoSrbija portal, a map of the basic ground cover was made, which more precisely shows the method of land use 
in 10 classes. A significant share of $49.14 \%$ is occupied by agricultural land, while deciduous forests are second in share, with $20.76 \%$ of the surveyed territory. Bare lands that would be most suitable for the potential location of a nuclear power plant according to this class, have a share of $0.29 \%$.

Protected natural assets are an elimination factor in finding a potential location for nuclear power plants in a specific research area. They occupy a total area of $1099.42 \mathrm{~km}^{2}$, which is $12.55 \%$ of the total research area. During the analysis, protected goods located outside the territory of the research area were taken into consideration, because the impact of nuclear power plants would very much apply to them as well. Thanks to a joint project of UNEP and IUCN, the World Database on Protected Areas (WDPA) was obtained and used in the paper.

Table 2. Evaluation of land use

\begin{tabular}{|c|c|c|c|}
\hline Land use & Grade & Land use & Grade \\
\hline Settlements & 1 & Meadows & 5 \\
\hline $\begin{array}{c}\text { Larger settlements } \\
\text { commercial zones }\end{array}$ & 1 & $\begin{array}{c}\text { Complex of agricultural } \\
\text { plots }\end{array}$ & 4 \\
\hline $\begin{array}{c}\text { Traffic } \\
\text { infrastructure } \\
\text { facilities }\end{array}$ & 1 & $\begin{array}{c}\text { Agricultural areas with } \\
\text { natural vegetation }\end{array}$ & 3 \\
\hline Ports & 1 & Deciduous forests & 2 \\
\hline Airports & 1 & Mixed forests & 2 \\
\hline $\begin{array}{c}\text { Exploitation of } \\
\text { mineral resources }\end{array}$ & 3 & Pastures & 4 \\
\hline Landfills & 3 & $\begin{array}{c}\text { Woody and shrubby } \\
\text { vegetation }\end{array}$ & 5 \\
\hline Construction sites & 2 & Beaches, sand and dunes & 3 \\
\hline Parks & 3 & Areas with sparse & 5 \\
\hline $\begin{array}{c}\text { Sports and } \\
\text { recreational } \\
\text { facilities }\end{array}$ & 2 & Swatation & 3 \\
\hline Agricultural land & 4 & Larger rivers & 3 \\
\hline Vineyards & 4 & Water surfaces & 3 \\
\hline Orchards & 4 & &
\end{tabular}


Application of GIS in selection of location for construction of nuclear power plants in Serbia

The proximity of the nuclear power plant to the state border is one of the most important safety criteria in the event of an accident. The Republic of Serbia borders eight countries, and if an emergency situation occurs, the impact would spread to surrounding countries, such as the 1986 Chernobyl accident. The most suitable areas with a distance of over 20 kilometers are represented with a share of $63.66 \%$.

Table 3. Evaluation of anthropogenic factors

\begin{tabular}{|c|c|c|c|}
\hline $\begin{array}{c}\text { Distance from the } \\
\text { state border }(\mathbf{k m})\end{array}$ & Grade & Distance from state roads $\mathbf{( k m )}$ & Grade \\
\hline$<5$ & 1 & $<3$ & 5 \\
\hline $5-10$ & 2 & $3-6$ & 4 \\
\hline $10-15$ & 3 & $6-9$ & 3 \\
\hline $15-20$ & 4 & $9-12$ & 2 \\
\hline$>20$ & 5 & $>12$ & 1 \\
\hline $\begin{array}{c}\text { Distance from } \\
\text { railways (km) }\end{array}$ & Grade & $\begin{array}{c}\text { Distance from the settlement } \\
(\mathbf{k m})\end{array}$ & Grade \\
\hline$<3$ & 5 & $<2.5$ & 1 \\
\hline $3-6$ & 4 & $2.5-5$ & 2 \\
\hline $6-9$ & 3 & $5-10$ & 3 \\
\hline $9-12$ & 2 & & \\
\cline { 1 - 2 } & 1 & &
\end{tabular}

Access to the main state roads and railways is an unavoidable factor in locating a nuclear power plant due to easier access to the power plant itself, but also the transport of radioactive waste to the disposal site. The content analysis concludes that the traffic infrastructure is at a satisfactory level because the areas of less than $3 \mathrm{~km}$ in the territory of the research area are most represented with a share of $72.03 \%$. Nuclear power plants as an anthropogenic creation have a great negative impact if an accident situation occurs. For this reason, it is important that settlements be as far away as possible from a potential nuclear power plant.

In order to obtain potential areas for the construction of nuclear power plants in the research area, a comparison of criteria in 3 groups was performed, and then a final comparison of the results obtained from each of the 3 groups separately. The criteria from the tables are placed in relation to each other, in order to then obtain matrices in order to further proceed towards obtaining the weighting coefficient for each criterion. 
Collection of Papers - Faculty of Geography at the University of Belgrade 69

Table 4. Assignment of values and comparison between parameters

\begin{tabular}{|c|c|c|c|c|}
\hline Group 1 & Geology & Seismic hazard & Slope & Faults \\
\hline Geology & 1 & 0.5 & 2 & 1.5 \\
\hline Seismicism & 2 & 1 & 2.5 & 2.5 \\
\hline Slope & 0.5 & 0.4 & 1 & 1 \\
\hline Faults & 0.667 & 0.4 & 1 & 1 \\
\hline Group 2 & Settlements & Roads & Railways & Border \\
\hline Settlements & 1 & 2.5 & 4 & 5 \\
\hline Roads & 0.4 & 1 & 2.5 & 3 \\
\hline Railways & 0.25 & 0.4 & 1 & 2 \\
\hline Border & 0.2 & 0.333 & 0.5 & 1 \\
\hline Group 3 & Land use & $\begin{array}{c}\text { Pedological } \\
\text { cover }\end{array}$ & $\begin{array}{c}\text { Protected } \\
\text { areas }\end{array}$ & \\
\hline Land use & 1 & 1 & 1.5 & \\
\hline $\begin{array}{c}\text { Pedological } \\
\text { cover }\end{array}$ & 1 & 1 & 1.5 & \\
\hline Protected areas & 0.667 & 0.667 & 1 & \\
\hline Groups & Group 1 & Group 2 & Group 3 & \\
\hline Group 1 & 1 & 3 & 4 & \\
\hline Group 2 & 0.333 & 1 & 2 & \\
\hline Group 3 & 0.25 & 0.5 & 1 & \\
\hline
\end{tabular}

The mathematical operation of squaring the matrix gives a new one, in which by summing the values for each row of the matrix (criterion) and dividing each sum of the row by the total sum, we obtain a coefficient, i.e. significance for each criterion.

Table 5. Coefficients of each parameter

\begin{tabular}{|c|c|c|c|}
\hline Criterion & Coefficient & Criterion & Coefficient \\
\hline Geology & 0.158807 & Railways & 0.031155 \\
\hline Seismicism & 0.269522 & Border & 0.01983 \\
\hline Slope & 0.09553 & Land use & 0.050887 \\
\hline Faults & 0.102447 & $\begin{array}{c}\text { Pedological } \\
\text { cover }\end{array}$ & 0.050887 \\
\hline Settlements & 0.124876 & Protected areas & 0.033925 \\
\hline Roads & 0.062134 & \multicolumn{2}{|l}{} \\
\cline { 2 - 3 }
\end{tabular}


Application of GIS in selection of location for construction of nuclear power plants in Serbia

The final coefficient of each parameter was obtained by multiplying the weight coefficient within the group to which it belongs and the weight coefficient of the group when compared with other groups. Furthermore, with the help of GIS, by multiplying each parameter with its final coefficients and mutual summation of parameters, the final map was obtained.

\section{Results and discussion}

By processing and analyzing the available data in geographic information systems and AHP, a synthesis map of the benefits of building nuclear power plants on the territory of the Republic of Serbia was obtained.

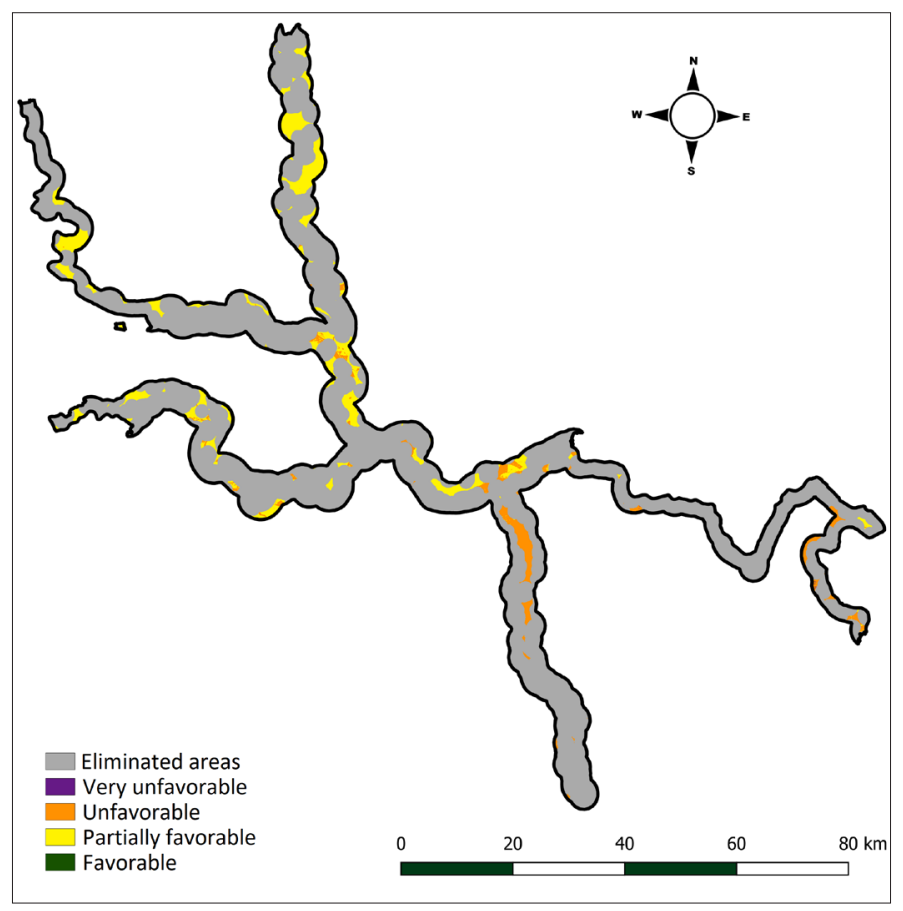

Figure 2. Synthesis map of suitability

Classified values are: eliminated areas, very unfavourable, unfavourable, partially favourable and favourable areas.

Eliminated areas include all protected natural assets located in or near the research area itself, as well as the distance from the settlement because it is impossible from several aspects to build a nuclear power plant on such 
areas. The most ideal areas are not even a few kilometers along the border, but if the two countries cooperate on the joint use of energy (such as Croatia and Slovenia), it is possible to find an adequate location.

Using the Analytic Hierarchy Process, a map of potential locations for the construction of nuclear power plants was obtained, where $88.15 \%$ of the research area was eliminated, $0.01 \%$ were extremely unfavourable areas for construction, $3.15 \%$ were unfavourable areas, $8.68 \%$ were partially favourable, and $0.002 \%$ of the territory was favourable for construction.

The most suitable locations are characterized by the presence of magmatic rocks, flat terrain at lower altitudes. These are areas with sparse vegetation that are far enough away from the faults and have the lowest seismic activity compared to other parts of the study area. The most suitable areas are far enough from the settlement and the state border, and are located near roads and railways, which would facilitate the transport of materials, both for the construction and during the operation of the nuclear power plant. It can be concluded from the map that in the village of Martonoš, which belongs to the municipality of Kanjiža, there are suitable and partially suitable areas for the construction of nuclear power plants. It is also interesting to note that in the zone of 5 kilometers from the river Velika Morava, only in the settlements of Mala Krsna, Skobalj and Osipaonica (which belong to the municipality of Smederevo) and in Pozarevac, there are partially suitable locations for the construction of nuclear power plants. The municipality of Negotin, with the settlements of Mihajlovac, Jabukovac and Mala Krsna, has extremely unsuitable areas for potential NPP locations.

In the areas around the Danube, partially suitable areas are in the municipalities of Apatin, Odžaci, Bač, Bačka Palanka, Šid, Novi Sad, Palilula, Pančevo, Kovin, Veliko Gradište and Kladovo. The Sava River in its zone also has partially suitable areas in certain municipalities. Sremska Mitrovica stands out especially because it offers the most such areas.

\section{Conclusion}

Geographic information systems allow users to visualize, research, analyze, and interpret the vast majority of data in order to gain a better understanding of the problem (Damoom et al., 2019). By analyzing natural and anthropogenic factors and using GIS technology, relevant results were obtained for potential locations for the construction of nuclear power plants 
Application of GIS in selection

of location for construction of nuclear power plants in Serbia

in an area of $8757.45 \mathrm{~km}^{2}$, which is about $10 \%$ of the entire territory of the Republic of Serbia.

Based on the obtained results, it can be concluded that $8.682 \%$ (760.3 $\mathrm{km}^{2}$ ) of the investigated territory is suitable or partially suitable for the construction of nuclear power plants. These are the areas that received the highest grades in the evaluation of natural and anthropogenic factors. Making a decision on the construction of a nuclear power plant is neither an easy nor a naive task because in addition to considering all natural and anthropogenic factors, the state should have a stable system and established laws so that work of NPP go smoothly and to react properly in any unfavorable situation.

In addition to cabinet work, it is necessary to validate the results in the field, as well as to assess the susceptibility of the most suitable areas to natural disasters: torrential floods, landslides, forest fires, soil erosion, etc. (Dragićević et al., 2011; Ristić et al., 2012; Novković et al., 2018; Blöschl et al., 2019; Durlević et al., 2019). For now, the main obstacle in Serbia regarding the issue of nuclear power plants is the moratorium that occurred after the Chernobyl accident. Lifting the moratorium in the future would enable more detailed research and possible construction of nuclear power plants, because the Republic of Serbia strives for European Union (EU) standards in reducing the use of fossil fuels for energy needs, so that nuclear energy with renewable energy sources in the coming decades would be a suitable support for production of zero-emission greenhouse gas electricity.

Nuclear power plants are extremely complex facilities and the radioactive waste that would be produced in them would be specially treated in order to minimize the risk to the environment. A large number of countries in the world and the region exploit nuclear energy because nuclear power plants continue to be one of the cleanest ways to obtain energy.

\section{References}

Atanasova-Pachemska, T., Lapevski, M. \& Timovski, R. (2014). Analytical hierarchical process (AHP) method application in the process of selection and evaluation. International scientific, conference II, 373-380.

Bennett, B., Repacholi, M. \& Carr, Z. (editors) (2006). Health effects of the Chernobyl accident and special health care programmes. Report of the UN Chernobyl Forum. Geneva: World Health Organization. 
Blöschl, G., Hall, J., Viglione, A., Perdigão, R. A. P., Parajka, J., Merz, B., Lun, D., Arheimer, B., Aronica, G. T., Bilibashi, A., Boháč, M., Bonacci, O., Borga, M., Čanjevac, I., Castellarin, A., Chirico, G. B., Claps, P., Frolova, N., Ganora, D., Gorbachova, L., Gül, A., Hannaford, J., Harrigan, S., Kireeva, M., Kiss, A., Kjeldsen, T. R., Kohnová, S., Koskela, J. J., Ledvinka, O., Macdonald, N., Mavrova-Guirguinova, M., Mediero, L., Merz, R., Molnar, P., Montanari, A., Murphy, C., Osuch, M., Ovcharuk, V., Radevski, I., Salinas, J. L., Sauquet, E., Šraj, M., Szolgay, J., Volpi, E., Wilson, D., Zaimi, K. \& Živković, N. (2019). Changing climate both increases and decreases European river floods. Nature, 573, 108-111.

Borzilov, V. A. \& Klepikova, N. V. (1993). Effectofmeteorological conditions and release composition on radionuclide deposition after the Chernobyl accident. In: Merwin SE, Balonov MI, editors. The Chernobyl papers. Richland: Research Enterprises, pp. 47-68.

Cvetković, V. M., Öcal, A., Lyamzina, Y., Noji, E. K., Nikolić, N. \& Milošević, G. (2021). Nuclear Power Risk Perception in Serbia: Fear of Exposure to Radiation vs. Social Benefits. Energies, 14, 2464.

Damoom, M. M., Hashim, S., Aljohani, S. M., Saleh, A. M. \& Xoubi, N. (2019). Potential areas for nuclear power plants siting in Saudi Arabia: GIS-based multi-criteria decision making analysis. Progress in Nuclear Energy, 110, 110-120.

Doderović, M., Mijanović I., Burić, D. \& Milenković, M. (2020). Assessment of the water quality in the Morača River basin (Montenegro) using water quality index. Bulletin of Serbian Geographical Society, 100 (2), 67-81.

Dragićević, S., Novković, I., Carević, I., Živković, N. \& Tošić, R. (2011). Geohazard Assesment in the Eastern Serbia. Forum Geografic, 10 (1), 10-19.

Durlević, U., Momčilović, A., Ćurić, V. \& Dragojević, M. (2019). Gis application in analysis of erosion intensity in the Vlasina River Basin. Bulletin of the Serbian geographical society, 99 (2), 17-36.

Durlević, U. (2020). The Analysis of the Quality of Surface Water of Danube in the Republic of Serbia for 2018. Collection of papers - Faculty of Geography at the University of Belgrade, 68, 53-70.

Ercan, O., Ural, E., Tekbiylk, A. (2015). Pre-Service Teachers' Attitudes Towards Nuclear Energy And The Effect Of Fukushima Nuclear Disaster On Their Attitudes. The International Journal of Social Sciences and Humanities Invention, Vol. 2 (11), 1669-1678. 
Application of GIS in selection

of location for construction of nuclear power plants in Serbia

Filipović, H. M. \& Kešetović, M. Ž. (2017). Risk perception and nuclear energy: literature review. Serbian Science Today, Vol. 2, No. 1, 67-77.

Forman, E. \& Selly, M. A. (2001). Decision By Objectives. River Edge. New Jersey: World Scientific Publishing.

Fukunaga, H. (2021). Disaster-related Deaths in Fukushima. Jpn. J. Health Phys., 56 (1), 26-27.

Kristiansen, S. (2017). Media and Risk: A Phase Model Elucidating Media Attention to Nuclear Energy Risk. Universitätsverlag Ilmenau: Münster, Germany, Vol. 5.

Langović, M., Manojlović, S. \& Čvorović, Z. (2017). Trends of mean annual river discharges in the Zapadna Morava river basin. Bulletin of Serbian Geographical Society, 97 (2), 19-45.

Makhonko, K. P., Kozlova, E. G. \& Volokitin, A. A. (1996). Radioiodine accumulation on soil and reconstruction of doses from iodine exposure on the territory contaminated after the Chernobyl accident. Radiat Risk, 7, 90-142.

Neumann, S. \& Hopf, M. (2013). Students' Ideas About Nuclear Radiation - Before and After Fukushima. Eurasia Journal of Mathematics, Science \& Technology Education, 9 (4), 393-404.

Novković, I., Dragićević, S., Živković, N., Tošić, R. \& Čvorović, Z. (2018). Vulnerability assessment of the Jošanička River Basin to torrential floods and forest fires. Advances in GeoEcology, 45 - Soil and water resources protection in the changing environment. Catena, 48-65.

Nuclear energy agency. (2003). Nuclear Energy Today: First Edition.

Park, E. \& Ohm, J. (2014). Factors influencing the public intention to use renewable energy technologies inSouth Korea: Effects of the Fukushima nuclear accident. Energy Policy, 65, 198-211.

Peters, E. \& Slovic, P. (1996). The role of affect and worldviews as orienting dispositions in the perception and acceptance of nuclear Power. Journal of applied social psychology, 26 (16), 1427-1453.

Preston, D. L., Ron, E., Tokuoka, S., Funamoto, S., Nishi, N., Soda, M., Mabuchi, K. \& Kodama, K. (2007). Solid cancer incidence in atomic bomb survivors: 1958-1998. Radiat. Res., 168, 1-64.

Rhodes, J. C. (2014). The Fukushima Daiichi nuclear accident. Science Progress, 97 (1), 72-86. 
Ristić, R., Kostadinov, S., Abolmasov, B., Dragićević, S., Trivan, G., Radić, B., Trifunović, M. \& Radosavljević, Z. (2012). Torrential floods and town and country planning in Serbia. Nat. Hazards Earth Syst. Sci., 12, 23-35.

Saaty, T. L. (1980). Analytic hierarchy process. McGraw-Hill, New York.

Saaty, T. L. (1990). How to make a decision: The analytic hierarchy process. European Journal of Operational Research, 48, 9-26.

Saenko, V., Ivanov, V., Tsyby, A., Bogdanova, T., Tronko, M., Demidchik, Yu. \& Yamashita, S. (2011). The Chernobyl Accident and its Consequences. Clinical Oncology 23, 234-243.

Sjöberg, L. (2000). Factors in Risk Perception. Risk Analysis, 20, 1-12.

Smith, K. (2013). Environmental hazards: assessing risk and reducing disaster. New York: Routledge.

Sundström, A. \& McCright, A. M. (2016). Women and nuclear energy: Examining the gender divide in opposition to nuclear power among swedish citizens and politicians. Energy Research \& Social Science, 11, 29-39.

Viklund, M. (2004). Energy policy options - from the perspective of public attitudes and risk perceptions. Energy policy, 32 (10), 1159-1171.

Visschers, V. H. M. \& Siegrist, M. (2013). How a Nuclear Power Plant Accident Influences Acceptance of Nuclear Power: Results of a Longitudinal Study Before and After the Fukushima Disaster. Risk Analysis, 33 (2), 333-347.

World nuclear association. (2021). Nuclear Power in the World Today.

Стојсављевић, С. (2008). Нуклеарне електране - утицај на животну средину. Дипломски рад. Нови Сад: Природно-математички факултет департман за физику, Универзитет у Новом Саду.

Хајдин, Б. \& Поломчић, Д. (2016). Утицај проширена нуклеарне електране "Пакш" (Мађарска) на ресурсе подземних вода у Војводини. Београд: Рударско-геолошки факултет, Универзитет у Београду.

Шестановић, С. (1997). Основе геологије и петрографије. Сплит: Грађевински факултет, Свеучилиште у Сплиту. 